\title{
THE DELANG ISOLECT: A SYNCHRONIC DESCRIPTION ON ITS PHONEMIC SYSTEM, RETENTION, AND INNOVATION
}

\author{
(Isolek Delang: Sebuah Deskripsi Sinkronis \\ terhadap Sistem, Pemertahanan, dan Inovasi Fonemiknya)
}

\author{
R. Hery Budhiono \\ Balai Bahasa Provinsi Kalimantan Tengah \\ Jalan Tingang Km. 3,5, Palangka Raya, Kalimantan Tengah 73112 \\ Pos-el: ralph.herybudhiono@kemdikbud.go.id
}

(Naskah Diterima 17 September 2021—Direvisi 24 September 2021—Disetujui 27 September 2021)

\begin{abstract}
Abstrak
Penelitian ini bertujuan untuk mengidentifikasi isolek Delang secara lebih mendalam, terlepas dari statusnya sebagai bahasa mandiri atau dialek dari bahasa lain. Penelitian ini diharapkan dapat memberikan pengetahuan kepada penutur isolek Delang khususnya dan masyarakat pada umumnya terkait dengan sistem, pemertahanan, dan inovasi fonemik dalam isolek itu. Metode yang digunakan dalam penelitian ini ialah deskriptif dengan pendekatan sinkronis-kualitatif. Data yang merupakan 200 kata dasar Swadesh dikumpulkan tahun 2019 oleh tim pemetaan Balai Bahasa Kalimantan Tengah dan berupa data mentah yang belum ditranskripsikan. Analisis dimulai dari deskripsi sistem fonemis isolek itu. Retensi dan inovasi fonemik didapatkan dari perbandingan antara 200 kosakata dasar isolek itu dan PAN versi Blust. Berdasarkan analisis diperoleh beberapa simpulan. Isolek Delang memiliki 5 vokal dan 18 konsonan. Beberapa fonem proto, seperti *a dan *u, pada posisi tertentu dipertahankan, sedangkan fonem lain diinovasikan atau diubah. Inovasi sekunder yang didapatkan ialah protesis, sinkope, metatesis, afaeresis, dan fortisi.
\end{abstract}

Kata kunci: inovasi, proto-Austronesia (PAN), retensi, sistem fonem

\begin{abstract}
Problem to be discussed in the research is how does the phonemic system of the Delang and its retention and innovation to be compared with its proto Austronesia $(P A N)$. This research is aimed to identify the character of the Delang descriptively, out from its status either as an independent language or just a dialect or subdialect of a certain language. The research hopefully can give more knowledge contributions especially for the speaker and the community at large. This is a descriptive research with synchronic-qualitative approach. The data will be 200 basic lexicons from Swadesh that is compiled by the language mapping team of Balai Bahasa Kalimantan Tengah in 2019. The analysis is started from the description of the Delang phonemic system. The phonemic retention and innovation come from comparing the lexicons with its Blust is PAN. Based on the analysis the writer underlined some conclusions. The isolect has 5 vowels and 18 consonants. Some protophonemes, like *a and $* u$ in certain positions, are maintained, while some other phonemes are innovated or substituted. Some secondary innovations found, namely prothesis, syncope, metathesis, aphaeresis, and fortition.
\end{abstract}

Keywords: innovation, phonemic system, proto-Austronesia $(\mathrm{PAN})$, retention 


\section{INTRODUCTION}

The largest language family in the world is known as Austronesia. The Austronesia is spoken spreadly and largely from Taiwan to New Zealand and from Madagascar to Easter Island. It consists of more than 1.000 languages. About 700 of its member are spoken in Indonesia (Collins, 2005).

One of hundreds member of Austronesia spoken in Indonesia is the Dayakese languages. Dayakese languages refer to some languages spoken by Dayakese in the mainland of Borneo or Kalimantan and its surroundings.

The languages spoken in Central Kalimantan mainly consists of three languages stocks. Poerwadi as stated in his classic paper mentioned that Central Kalimantan consists of three major language stocks. They are West Central Kalimantan Stock and East Kalimantan Stock. Within these stocks stand about three language families. They are Bawo Family within the East Stock and Ut Danum and Tamuan family within West Kalimantan stock.

Meanwhile, the West Kalimantan Stock consists of two main families of language, namely the familiy of Ut Danum and Tamuan. Within the family of Tamuan, there is a subfamily language of Lamandau. The Delang isolect, which is the focus of this paper, is the member of this subfamily of language (Poerwadi, 1994).

Poerwadi stated that the Delang is only the dialect of the language of Lamandau. The language of Lamandau consists of three main dialects. They are Pangkut, Delang, and Melata.

However, that assumption should be clarified and revisited. As a matter of facts, the research conducted by Poerwadi is taken place in 1994. It has been 27 years ever since. The method he used is lexicostatistics. In present time, some researches deal with the languages and language families in Central Kalimantan should be executed comprehensively by using some better methods.

Central Kalimantan consists of 26 different languages with about 50 dialects and hundreds of subdialects. The data is retrieved from the recent researches conducted by a team from Balai Bahasa Kalimantan Tengah. The language of social and commerce will be the Malay Banjar. The lingua franca used as the medium language among the Dayakese is the Ngaju Dayak.

The Ngaju Dayak is spoken largely and widely in Central Kalimantan. It spoken in the west, central, and north-east region of the province. But, the role of the language is diminished significantly since the younger speakers show lack of competency in using the language in daily activities.

In the other side, there is merely no sufficient references in accordance with the isolect of Delang. No such comprehensive and satisfied research deals with the Delang isolect nowadays.

The Delang is spoken widely enough in the region of Delang Subdistrict, Lamandau Regency. It is spoken largely in the villages of Sei Tuat and Kubung. Sei Tuat and Kubung villages will be the main locus of the research. Along with the Delang, the languages spoken in the region is Tomuan.

There are some similarities between the Ngaju Dayak and the Delang. The lexicon of bintang 'star', bulan 'moon', buah 'fruit', danau 'lake', langit 'sky', and laut 'sea' show some similar realizations. The other lexicons either show some similarities. The lexicons of lima 'five', luka 'wound', panjang 'long', and tertawa 'laugh' seems to be similar. 
According to the background mentioned above the writer would like to give some descriptions about the Delang and analyze its phonemic retention and innovations within. The main object of the research is the Delang isolect. Phonemes in the Delang are then compared with some proto Austronesian etima by Blust (Blust, 1981, 1999). This problem should be grounded on the facts that phonemes of the language is the most dynamic aspect to be innovated and changed.

To investigate the phenomena, the writer firstly stands on the definition of the phoneme. Phoneme is the smallest and distinctive units in language (Crowley, 1992). For example, the $/ \mathrm{k} /$ in kalah 'lose' is a different phoneme from /g/ as in galah 'vault'. As well as the /e/ in seri 'draw' is a different phoneme from /a/ in sari 'essence'. The /c/ in kaca 'glass' is a different phoneme from $/ t /$ in kata 'word'.

The writer then gives some explanations about historical linguistics as the main frame of the research. Historical linguistics is a branch of linguistics which identifies and categorizes certain languages. It also observes some changes within the language and figure out what factors involved (Bynon, 1971).

In historical linguistics several cognate words are identified to find its genetic relationship. All possible cognate words from certain languages are compared. As the result, the term protolanguage is used by linguists. Blust stated that a protolanguage is a hypothetically ancestor of a group of attested languages which is inferred, or reconstructed, on the basis of systematic similarities among its attested descendants (Blust, 1981).

Some scholars have compiled and constructed protoform of some Austronesian languages or hereafter said as proto-Austronesian (PAN). One of them is Blust. Blust, as in Crowley and Bynon, stated that protolanguage is a conceptual and theoretical design in relation with the system of a certain language family (Blust, 1981; Bynon, 1971; Crowley, 1992).

As stated above, no sufficient references deal with the isolect of Delang. But, in the domain of language description and phonemic and retention there are several researches conducted by scholars. In the domain of language description and phonemic retentions and innovations there are also plenty of papers.

Masrukhi in his paper entitled "Refleksi Fonologis Protobahasa Autsronesia pada Bahasa Lubu" concluded that the Lubu has 20 consonants. Some proto-Austronesian maintained are ${ }^{*} \mathrm{~b},{ }^{*} \mathrm{c},{ }^{*} \mathrm{~d},{ }^{*} \mathrm{D},{ }^{*} \mathrm{k},{ }^{*} \mathrm{p}$, and $* \mathrm{t}$. He concluded also that there are two kinds of secondary innovations namely split and merger (Masrukhi, 2002).

Tiani in her paper published by Nusa entitled "Korespondensi Fonemis Bahasa Palembang dan Bahasa Riau" stated that those two languages are descended from the same big stock, namely Austronesia. Some correspondences found are $/ \mathrm{r} \sim \varnothing /, / \mathrm{a} \sim \mathrm{O} /$, /ə a / and /j t / (Tiani, 2018).

Antono et al in their paper entitled "Pemertahanan Fonologis dan Leksikal Bahasa Jawa di Kabupaten Wonogiri: Kajian Geografi Dialek" mentioned that $* \mathrm{i}, * \mathrm{u}, *^{*},{ }^{*} \mathrm{o}, * \mathrm{a}, * \mathrm{~b},{ }^{*} \mathrm{c},{ }^{*} \mathrm{~d},{ }^{*} \mathrm{~g}, * \mathrm{k}, * \mathrm{j}$, $*_{\mathrm{m}}, *_{\mathrm{n}}, * \mathrm{p}, * \mathrm{r}, *_{\mathrm{s}}, *_{\mathrm{t}},{ }^{*} \mathrm{w}$, and $* \mathrm{y}$ are maintained. In the lexicons domain there are 117 lexicons in 18 semantic fields are also maintained (Antono, 2019).

Aqromi and Hendrawan published a paper entitled "Bahasa tidung di Kalimantan Utara: Sebuah Tinjauan Linguisti Diakronis". They concluded that $* \mathrm{k}, * \mathrm{l}, * \mathrm{t}, * \mathrm{a}$, and $*^{\mathrm{u}}$ are maintained in Tidung. They also found two primary 
innovations namely split and merger and one secondary innovation, fortition, in the Tidung (Aqromi \& Hendrawan, 2019).

Rinah in her thesis entitled "Hubungan Kekerabatan Bahasa Malagasy dan Bahasa Maanyan" concluded that some vowels and consonants in those languages are closely related. Those two languages seems have some shared innovations (Rinah, 2010).

Reflects of PAN in the language of Madura is written by Azhar. He said that the degree of cognates in the language of Madura and PAN is significantly high. Plenty of PAN are maintained in Madura language (Azhar, 2010).

Hasrah et al in their research entitled "Inovasi dan Retensi dalam Dialek Hulu Tembeling" concluded that there is certain innovation in the Hulu Tembeling dialect, namely consonantal monophtongization. Two protophonemes, namely $*_{\mathrm{I}}$ and $* \mathrm{u}$, are maintained in penultimate position (Hasrah, 2013).

"Retensi dan Inovasi Fonologis Protobahasa Melayik pada Bahasa Melayu Tamiang" is written by Toha. He concluded that there are six consonants maintained, namely $*^{*} \mathrm{~h},{ }^{*} \mathrm{k},{ }^{*} \mathrm{l},{ }^{*} \mathrm{r},{ }^{*} \mathrm{~s}$, and $*$ t. There are two vowels mintained namely *u and *a (Toha, 2016).

A research on the isolect's neighbour is conducted by Yulianti (Yulianti, 2016). In her research entitled "Variasi Dialektal Bahasa Tomuan", Yulianti concluded that the language of Tomuan is spoken in Menthobi Raya and Bulik Subdistrict, Lamandau Regency. The Tomuan has one dialect, the Bulik, and two subdialects, the Lubuk Hiju and Guci.

Based on some previous literatures reviewed above, there has been no comprehensive researches associated with the isolect of Delang. The phonemic system of the isolect and its retention and innovation has not been described and discussed either. This is the advantage of this research. This research aimed to fill the gap in order to give description and contribution scientifically for the given isolect.

\section{RESEARCH METHOD}

This descriptive and synchronic research uses qualitative approach. Moleong suggested that a qualitative research refers to a research uses some qualitative ways namely observation, interview or literature review (Moleong, 2015).

Sudaryanto said that descriptive method refers to the current facts and captured exactly as it real conditions (Sudaryanto, 2015). In advance, he suggests three steps in conducting the research namely data providing, data analysis and presentation of the result.

The secondary data source is taken from 200 basic vocabularies in Swadesh version. The words are listed in 2019 by the language mapping team of Balai Bahasa Provinsi Kalimantan Tengah. The questionnaire used to provide data is arranged by Pusat Bahasa for the purpose of language mapping in 2005. The questionnaire contains more than 1.100 vocabularies in 13 different categories, such as Swadesh's basic vocabularies, body parts, pronouns, kinship, and food and beverages (Pusat Bahasa, 2005).

The Delang isolect to be discussed in the research refers to one which is widely spoken in Kubung and Sei Tuat village, Delang Subdistrict, Lamandau Regency, and the surroundings. The one spoken in Kubung hereafter is symbolized with $K b$., while one is spoken in Sei Tuat is symbolized with St.

The features of type and sound changes from Crowley is used to analyze the data (Crowley, 1992). The data collected then described and compared with its etima listed by Blust to find phonemic innovation and retention. 
RESULT AND DISCUSSION

\section{Phonemic System of The Delang}

In relation to give description about the innovation and retention in the isolect of Delang, firstly the writer needs to present its phonological system. Just like any other Dayakese languages, the isolect of Delang has five vowels namely /a/, /e/, /i/, /o/, and /u/. In addition it has 19 consonants. They are /b/, /c/, /d/, /g/, /h/, /j/, /k/, /m/, /n/, /p/, /r/, /s/, /t/, /w/, /y/, /y/, $/ \check{\mathrm{n}} /$, and $/$ ?/. The vowels and consonants will be listed below on the table 1 and table 2 .

Table 1 Vowels in The Delang

\begin{tabular}{|l|l|l|l|}
\hline & \multicolumn{1}{|c|}{ Front } & Center & Back \\
\hline High & i & & u \\
\hline Mid & e & & o \\
\hline Low & & a & \\
\hline & & & \\
\hline
\end{tabular}

Table 2 Consonants in The Delang

\begin{tabular}{|c|ll|ll|ll|ll|r|}
\hline PoA & Labial & Dental & Palatal & Velar & Glottal \\
\cline { 1 - 7 } MoA & & & & & & & \\
\hline Stop & p & b & t & d & c & j & k & g & $?$ \\
\hline Nasal & m & n & n & & y & \\
\hline Fricative & & s & & & & & h \\
\hline Thrill & & r & & & \\
\hline Semivowel & w & & & y & & \\
\hline
\end{tabular}

Phonemic Retentions in The Delang

Retention refers to the protophoneme that is maintained in a modern language (Crowley, 1992). The followings are the protophoneme maintained in the Delang.

(1) $* \mathrm{a}>\mathrm{a} / \mathrm{K}-\mathrm{K}(* \mathrm{a}$ is maintained in interconsonant position)

Examples:

$\begin{array}{lll}\text { PAN } & \text { Realization } & \text { Glos. } \\ \text { *qabu } & \begin{array}{l}\text { Kb. habu } \\ \text { St. habu }\end{array} & \\ & \text { Kb. batu } & \text { stone } \\ \text { *batu } & \begin{array}{l}\text { St. batu } \\ \text { *ma-baqeRu }\end{array} & \begin{array}{l}\text { Kb. baharu } \\ \text { new }\end{array} \\ & \text { St. baharu } & \\ \text { *bulan } & \text { Kb. bulan } & \text { moon } \\ & \text { St. bulan } & \\ \text { *daRaq } & \text { Kb. darah } & \text { blood }\end{array}$

St. darah

\begin{tabular}{|c|c|c|}
\hline *Sepat & $\begin{array}{l}\text { Kb. ompat } \\
\text { St. ompat }\end{array}$ & four \\
\hline *kaRaw & $\begin{array}{l}\text { Kb. gayu } \\
\text { St. gayu }\end{array}$ & scratch \\
\hline$*$ quzaN & $\begin{array}{l}\text { Kb. hujatn } \\
\text { St. hujat }\end{array}$ & rain \\
\hline *qaqay & $\begin{array}{l}\text { Kb. kaki } \\
\text { St. kaki }\end{array}$ & foot \\
\hline *ka-wanaN & $\begin{array}{l}\text { Kb. kanan } \\
\text { St. kanan }\end{array}$ & right \\
\hline layiC & $\begin{array}{l}\text { Kb. lanit } \\
\text { St. lanit }\end{array}$ & sky \\
\hline$*_{\mathrm{maCa}}$ & $\begin{array}{l}\text { Kb. mato } \\
\text { St. mata }\end{array}$ & eye \\
\hline *m-aCay & $\begin{array}{l}\text { Kb. matiqi } \\
\text { St. mati }\end{array}$ & dead \\
\hline $\operatorname{taq}$ & $\begin{array}{l}\text { Kb. mutah } \\
\text { St. mutah }\end{array}$ & vomit \\
\hline Cazem & $\mathrm{Kb}$. tajapm & sharp \\
\hline
\end{tabular}




\begin{tabular}{|c|c|c|c|c|c|}
\hline \multirow{3}{*}{ *CaliS } & St. tajap & \multirow{3}{*}{ rope } & \multirow{3}{*}{ *ma-puňi } & \multicolumn{2}{|l|}{ St. tiduq } \\
\hline & Kb. tali & & & Kb. putih & white \\
\hline & St. tali & & & St. putih & \\
\hline \multirow[t]{2}{*}{ *Cawa } & $\mathrm{Kb}$. totawo & laugh & $* \mathrm{duSa}$ & $\mathrm{Kb}$. duo & two \\
\hline & St. tatawa & & & St. dua & \\
\hline \multirow[t]{2}{*}{ *Cuqelay } & $\mathrm{Kb}$. tulaky & bone & $*$ bulu & Kb. bulu & feather \\
\hline & St. tulak & & & St. bulu & \\
\hline \multirow[t]{2}{*}{ *Sular } & Kb. ular & snake & *qituy & Kb. hituky & count \\
\hline & St. ular & & & St. hituk & \\
\hline \multirow[t]{2}{*}{ *ma-tuqas } & Kb. tuho & old & *qijuy & Kb. hiduky & nose \\
\hline & St. tuha & & & St. hiduk & \\
\hline
\end{tabular}

(4) $* b>b / \# K-(* b$ is maintained in penultimate position)

(2) $*_{\mathrm{u}}>\mathrm{u} /$-\#K $\left(*^{\mathrm{u}}\right.$ is maintained in ultimate position)

Examples:

\begin{tabular}{|c|c|c|}
\hline \multirow{3}{*}{$\begin{array}{l}\text { PAN } \\
* \text { qabu }\end{array}$} & Realization & Glos. \\
\hline & Kb. habu & ash \\
\hline & St. habu & \\
\hline \multirow[t]{2}{*}{ *batu } & Kb. batu & stone \\
\hline & St. batu & \\
\hline \multirow[t]{2}{*}{ *ma-baqeRu } & Kb. baharu & new \\
\hline & St. baharu & \\
\hline \multirow[t]{2}{*}{$* \mathrm{kuCu}$} & Kb. kutu & lice \\
\hline & St. kutu & \\
\hline \multirow[t]{2}{*}{$*$ susu } & Kb. susu & breast \\
\hline & St. susu & \\
\hline
\end{tabular}

Examples:

\begin{tabular}{|c|c|c|c|c|c|}
\hline \multicolumn{3}{|c|}{ interconsonant position) } & PAN & Realization & Glos. \\
\hline Examples: & & & *daRaq & Kb. darah & blood \\
\hline PAN & Realization & Glos. & & St. darah & \\
\hline *bulan & $\begin{array}{l}\text { Kb. bulan } \\
\text { St. bulan }\end{array}$ & moon & *danaw & $\begin{array}{l}\text { Kb. danaw } \\
\text { St. danaw }\end{array}$ & lake \\
\hline *ma-buRaq & $\begin{array}{l}\text { Kb. buruk } \\
\text { St. buRuq }\end{array}$ & ugly & $* \mathrm{duSa}$ & $\begin{array}{l}\text { Kb. duo } \\
\text { St. dua }\end{array}$ & two \\
\hline *ikuR & $\begin{array}{l}\text { Kb. ikuq } \\
\text { St. ikuq }\end{array}$ & tail & (6) $* \mathrm{k}>1$ & $\mathrm{~K}-{ }^{*} \mathrm{k} \mathrm{k}$ is $\mathrm{m}$ & ntained \\
\hline *quzaN & $\begin{array}{l}\text { Kb. hujatn } \\
\text { St. hujat }\end{array}$ & rain & $\begin{array}{l}\text { penulti } \\
\text { Examples: }\end{array}$ & te position) & \\
\hline *ma-tuqas & $\begin{array}{l}\text { Kb. tuho } \\
\text { St. tuha }\end{array}$ & old & $\begin{array}{l}\text { PAN } \\
\text { *ka-wanaN }\end{array}$ & $\begin{array}{l}\text { Realization } \\
\text { Kb. kanan }\end{array}$ & $\begin{array}{l}\text { Glos. } \\
\text { right }\end{array}$ \\
\hline *Cuqelay & $\begin{array}{l}\text { Kb. tulaky } \\
\text { St. tulak }\end{array}$ & bone & $* \mathrm{kuCu}$ & $\begin{array}{l}\text { St. kanan } \\
\text { Kb. kutu }\end{array}$ & lice \\
\hline *Sular & $\begin{array}{l}\text { Kb. ular } \\
\text { St. ular } \\
\text { Kb. tiduq }\end{array}$ & $\begin{array}{l}\text { snake } \\
\text { sleep }\end{array}$ & *kulit & $\begin{array}{l}\text { St. kutu } \\
\text { Kb. kulit } \\
\text { St. kulit }\end{array}$ & skin \\
\hline
\end{tabular}

Examples:

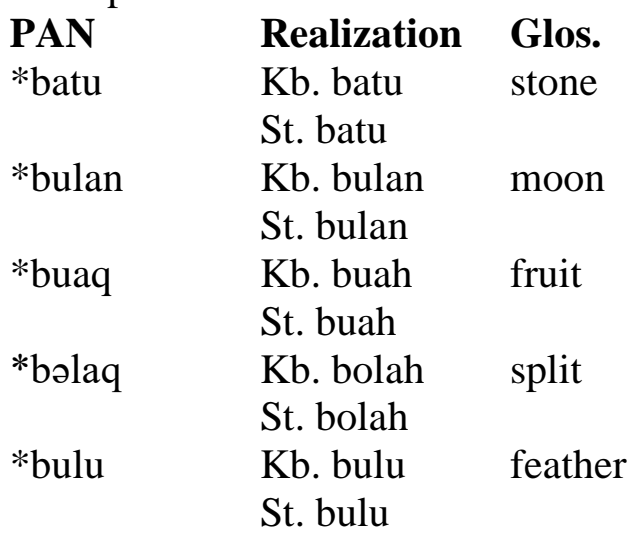

(5) $* \mathrm{~d}>\mathrm{d} / \# \mathrm{~K}-(* \mathrm{~d}$ is maintained in penultimate position)

Examples:

(6) $* \mathrm{k}>\mathrm{k} / \# \mathrm{~K}-(* \mathrm{k}$ is maintained in penultimate position)

Examples: 
*kərin

$$
\begin{aligned}
& \text { Kb. koriky dry } \\
& \text { St. korik }
\end{aligned}
$$

(7) $* m>m / \# \mathrm{~K}-(* m$ is maintained in penultimate position)

Examples:

$\begin{array}{lll}\text { PAN } & \text { Realization } & \text { Glos. } \\ \text { *maCa }^{\text {Kb. mato }} & \text { eye } \\ & \text { St. mata } & \\ \text { *m-aCay }^{\text {Kb. matiqi }} & \text { dead } \\ & \text { St. mati } & \end{array}$

(8) $* \mathrm{t}>\mathrm{t} / \# \mathrm{~K}-(* \mathrm{t}$ is maintained in penultimate position)

Examples:

$\begin{array}{lll}\text { PAN } & \text { Realization } & \text { Glos. } \\ \text { *tuduR } & \text { Kb. tiduq } & \text { sleep } \\ & \text { St. tiduq } & \\ \text { *talih } & \text { Kb. tali } & \text { rope } \\ & \text { St. tali } & \end{array}$

Phonemic Innovations in The Delang

Phonemic innovation refers to a certain protophoneme that are innovated or substituted in a modern language. The changes of protophonemes to become another phoneme is regular or sometimes irregular. Regular phoneme change is then called primary innovation, while irregular phoneme change is called secondary innovation (Crowley, 1992).

\section{Primary Innovations}

As stated above, primary innovation refers to certain regular and consistent protophoneme change into another phoneme in the modern language (Crowley, 1992). Based on the data, substitution is the only primary innovation found. The list below describes phoneme substitution in the Delang.
(1) ${ }^{*} \mathrm{q}>\mathrm{h} / \# \mathrm{~K}-\left({ }^{*} \mathrm{q}\right.$ is substituted into $\mathrm{h}$ in penultimate positions)

$\begin{array}{lll}\text { Examples: } & & \\ \text { PAN } & \begin{array}{l}\text { Realization } \\ \text { *qabu }\end{array} & \begin{array}{l}\text { Glos. habu } \\ \text { ash }\end{array} \\ & \text { St. habu } & \\ \text { *qaCay } & \text { Kb. hati } & \text { liver } \\ & \text { St. hati } & \\ \text { *ma-qudip } & \text { Kb. hidup } & \text { alive } \\ & \text { St. hidup } & \\ \text { *quzaN } & \text { Kb. hujatn } & \text { rain } \\ & \text { St. hujat } & \end{array}$

(2) $* \mathrm{q}>\mathrm{h} / \mathrm{-K} \#\left(*^{*} \mathrm{q}\right.$ is substituted into $\mathrm{h}$ in ultimate positions)

Examples:

$\begin{array}{lll}\text { PAN } & \text { Realization } & \text { Glos. } \\ \text { *bəlaq } & \text { Kb. bolah } & \text { split } \\ & \text { St. bolah } & \\ \text { *buaq } & \text { Kb. buah } & \text { fruit } \\ & \text { St. buah } & \\ \text { *daRaq } & \text { Kb. darah } & \text { blood } \\ & \text { St. darah } & \\ \text { *utaq } & \text { Kb. mutah } & \text { vomit } \\ & \text { St. mutah } & \end{array}$

(3) $* \mathrm{C}>\mathrm{t} / \# \mathrm{~K}-\left({ }^{*} \mathrm{C}\right.$ is substituted into $\mathrm{t}$ in penultimate positions)

Examples:

$\begin{array}{llc}\text { PAN } & \text { Realization } & \text { Glos. } \\ \text { *Cazem } & \text { Kb. tajapm } & \text { sharp } \\ & \text { St. tajap } & \\ * \text { *alis } & \text { Kb. tali } & \text { rope } \\ & \text { St. tali } & \\ * \text { Cuqelay } & \text { Kb. tulaky } & \text { bone } \\ & \text { St. tulak } & \\ \text { *Cawa } & \text { Kb. totawo } & \text { laugh } \\ & \text { St. tatawa } & \end{array}$

(4) $* \mathrm{C}>\mathrm{t} / \mathrm{V}-\mathrm{V}\left({ }^{*} \mathrm{C}\right.$ is substituted into $\mathrm{t}$ in intervowel positions)

Examples:

$\begin{array}{lll}\text { PAN } & \text { Realization } & \text { Glos. } \\ * \mathrm{kuCu} & \text { Kb. kutu } & \text { lice } \\ & \text { St. kutu } & \\ * \mathrm{maCa} & \text { Kb. mato } & \text { eye } \\ & \text { St. mata } & \end{array}$




\begin{tabular}{|c|c|c|}
\hline *m-aCay & $\begin{array}{l}\text { Kb. matiqi } \\
\text { St. mati }\end{array}$ & dead \\
\hline *qaCay & $\begin{array}{l}\text { Kb. hati } \\
\text { St. hati }\end{array}$ & liver \\
\hline $\begin{array}{l}\text { (5) } * \mathrm{R}>\mathrm{r} / \\
\text { in inter }\end{array}$ & $\begin{array}{l}\mathrm{V} \text { (* } \mathrm{R} \text { is subst } \\
\text { wel positions) }\end{array}$ & $d \mathrm{i}$ \\
\hline Examples: & & \\
\hline PAN & Realization & Glos. \\
\hline *daRaq & $\begin{array}{l}\text { Kb. darah } \\
\text { St. darah }\end{array}$ & blood \\
\hline *ma-buRaq & $\begin{array}{l}\text { Kb. buruk } \\
\text { St. buRuq }\end{array}$ & ugly \\
\hline
\end{tabular}

(6) $* S>\varnothing / \# \mathrm{~K}-(* \mathrm{~S}$ is substituted into $\varnothing$ in penultimate positions)

Examples:

$\begin{array}{lll}\text { PAN } & \text { Realization } & \text { Glos. } \\ \text { *Sapuy } & \text { Kb. api } & \text { fire } \\ & \text { St. api } & \\ \text { *Sular } & \text { Kb. ular } & \text { snake } \\ & \text { St. ular } & \\ \text { *Sepat } & \text { Kb. ompat } & \text { four } \\ & \text { St. ompat } & \end{array}$

(7) $*_{\mathrm{Z}}>\mathrm{j} / \# \mathrm{~K}-\left(*_{\mathrm{z}}\right.$ is substituted into $\mathrm{j}$ in penultimate positions)

Examples:

$\begin{array}{lll}\text { PAN } & \text { Realization } & \text { Glos. } \\ \text { *zahit } & \text { Kb. zohit } & \text { sew } \\ & \text { St. jahit } & \\ \text { *zalan } & \text { Kb. jalatn } & \text { road } \\ & \text { St. jalat } & \end{array}$

\section{Secondary Innovations}

Vice versa to the primary innovation, secondary innovation refers to certain inconsistent and irregular phoneme change. Some kinds of secondary innovations are listed below.

\section{Prothesis}

Prothesis is a kind of secondary innovations which refers to the addition of phoneme in penultimate position
(Crowley, 1992). The list of examples of prothesis are listed below.

$\begin{array}{lll}\text { PAN } & \text { Realization } & \text { Glos. } \\ \text { *utaq } & \text { Kb. mutah } & \text { vomit } \\ & \text { St. mutah } & \\ \text { *Cawa } & \text { Kb. totawo } & \text { laugh } \\ & \text { St. tatawa } & \end{array}$

\section{Syncope}

Syncope is a secondary innovations which refers to the omission of certain phonemes in the middle of the word (Crowley, 1992). Here are the examples of syncope.

\begin{tabular}{|c|c|}
\hline PAN & Realization \\
\hline *ka-wanaN & $\begin{array}{l}\text { Kb. kanan } \\
\text { St. kanan }\end{array}$ \\
\hline *ma-baqeRu & $\begin{array}{l}\text { Kb. baharu } \\
\text { St. baharu }\end{array}$ \\
\hline
\end{tabular}

\section{Metathesis}

Metathesis is a kind of secondary innovation which refers to the change of phonemes in order (Crowley, 1992). The examples of metathesis are discribed below.

$\begin{array}{lll}\text { PAN } & \text { Realization } & \text { Glos. } \\ \text { *ma-qudip } & \begin{array}{l}\text { Kb. hidup } \\ \text { alive }\end{array} & \\ & \text { St. hidup } & \\ \text { *qijuy } & \text { Kb. hiduky } & \text { nose } \\ & \text { St. hiduk } & \end{array}$

\section{Aphaeresis}

Aphaeresis is defined as the dropping of some initial consonants (Crowley, 1992). The examples of aphaeresis are listed below.

\begin{tabular}{|c|c|}
\hline PAN & Realization \\
\hline *ma-baqeRu & $\begin{array}{l}\text { Kb. baharu } \\
\text { St. baharu }\end{array}$ \\
\hline *ma-qaRiw & $\begin{array}{l}\text { Kb. koriky } \\
\text { St. korik }\end{array}$ \\
\hline
\end{tabular}




\section{Fortition}

Fortition is a secondary innovation which refers to the strengthening of a phoneme. Strengthening, in addition, is the change of a weak phoneme into strong one, from voiceless into voiced one (Crowley, 1992). Below are the examples of fortition.

$\begin{array}{lll}\text { PAN } & \text { Realization } & \text { Glos. } \\ \text { *qaqay } & \text { Kb. kaki } & \text { foot } \\ & \text { St. kaki } & \\ \text { *kaRaw } & \text { Kb. gayu } & \text { scratch } \\ & \text { St. gayu } & \end{array}$

After describing and analyzing the Delang phonemic system and its retention and innovations, the writer then comes to some underlined points. The Delang has six vowels and 18 consonants. Some of its lexicons seems to be borrowed from its surrounding language. The lexicons like habu 'dust', kuduq 'dog', and silu 'nail' most likely come from the Ngaju Dayak. Since it is spoken in the same big area of Central Kalimantan, it is not a bizarre phenomenon. Some languages treat the surrounding ones to enrich each other lexicons.

But, many of the Delang lexicons seems to be similar with the Malay language. The lexicons like banyak 'many', baharu 'new', beberopa 'some', semuo 'all', kepalo 'head', tobal 'thick', and tuho 'old' are very similar with the Malay with its dominant /o/. Some internal innovations then applied. The mid-back vowel /o/ are very dominant in the Delang. Some schwa /a/ are innovated and substituted into $/ \mathrm{o} /$.

This feature is also more likely to certain language which is spoken in the Menthobi Raya and Bulik Subdistrict, Lamandau Regency. The language of Tomuan shows some similar phonemic feature: the change of schwa /a/ into /o/ (Yulianti, 2016).
The most interesting thing in the Delang is the fact that it shares certain morphophonemic features with one of Dayakese languages, namely the Kanayatn. In Kanayatn, according to Astonis et al, -atn suffix has two allomorph, namely -atn and -an (Astonis, n.d.). In the Delang, there are some unique suffixes, i.e. $-k \eta$, $-t n$, and $p m$. The following list should describe the phenomena more clearly.

$\begin{array}{cl}\text { bintay } & \text { Kb. bintaky 'star' } \\ & \text { St. bintay } \\ \text { hidun } & \text { Kb. hiduky 'nose' } \\ & \text { St. hiduk } \\ \text { makan } & \text { Kb. makatn 'eat' } \\ & \text { St. makat } \\ \text { tahun } & \text { Kb. tahutn 'year' } \\ & \text { St. tahut } \\ \text { ti }{ }^{y} \text { up } & \text { Kb. mi }{ }^{y} \text { upm 'blow' } \\ \text { tajam } & \text { St. ti }{ }^{y} \text { up } \\ & \text { Kb. tajapm 'sharp' } \\ & \text { St. tajap }\end{array}$

From the list it can be concluded that the phoneme prior to the ultimate one should be homorgant. In the $\mathrm{Kb}$. although it is more complicated, these phenomena seem to be consistent and either in the St. This is a very unique character of those two Delang isolects. These kinds of ultimate soundings should be studied in a more comprehensive way to find out whether it is consistent or rather be sporadically happen.

Further, the writer also concluded that those two isolects show high similarities in the domain of phonemic and lexicon. Which one is older or superior than the other should be tested by using certain technique or method.

\section{CONCLUSION}

By observing the result of the analysis, the writer has identified the following conclusions. The Delang synchronically 
has 18 consonants and 5 vowels. The $*_{a}$ in interconsonantal position, ${ }^{*} \mathrm{u}$ in ultimate and interconsonantal position, $* \mathrm{~b}, *_{\mathrm{d}}$. $* \mathrm{k}, * \mathrm{~m}$, and $*_{\mathrm{t}}$ in penultimate position are maintained in the modern language.

The $* \mathrm{q}$ is innovated into $/ \mathrm{h} /$ in penultimate and ultimate position; ${ }^{*} \mathrm{C}$ is innovated into $/ \mathrm{t} /$ in penultimate and intervowels position; $* \mathrm{R}$ is innovated into $/ \mathrm{r} /$ in intervowels position; $*_{\mathrm{Z}}$ is innovated into $/ \mathrm{j} /$ in penultimate position; and $* S$ is ommitted in the penultimate position.

Some secondary innovations found are prothesis, syncope, metathesis, aphaeresis, and fortition.

However, this research is tend to be limited in the isolect phonemic system, retention, and innovation. In other domain, its lexicon, morphology, and syntax system should be analyzed further.

In line with that, the writer suggests other scholars to conduct different researches deal with the Delang isolect. The topic of its morphophonemic features should also be a very interesting one to be discussed. The consonant clusters of the given isolect can be compared with some other isolects or languages. Thus, its systems and consistency can be identified more clearly and comprehensively.

The status of the isolect is eventually should be revealed. Either the one is older or superior than another one should be clarified. Which subfamily or group the isolect belongs to would be a very challenging topic to be studied. Lexicostatistic and dialectometry can be used to come to the final conclusion.

\section{BIBLIOGRAPHY}

Antono, A. et. al. (2019). Pemertahanan Fonologis dan Leksikal Bahasa Jawa di Kabupaten Wonogiri:
Kajian Geografi Dialek. Jurnal Sastra Indonesia, 8(1), 23-32. https://doi.org/10.15294/jsi.v8i1.2 9854

Aqromi, N. L., \& Hendrawan, F. (2019). Bahasa Tidung di Kalimantan Utara: Sebuah Tinjauan dari Perspektif Diakronis. Kembara, 4(2), 200-207. https://doi.org/10.22219/KEMBA RA.Vol4.No2.200-207

Astonis, S. S. et. al. (n.d.). Afiksasi Bahasa Dayak Kanayatn dalam Kitab Papakatn Barahu. http://download.garuda.ristekdikti. go.id/article.php?article $=1562540$ $\&$ val $=2338 \&$ title $=$

Azhar, I. N. (2010). Jejak Proto Bahasa Austronesia pada Bahasa Madura. Metalingua, 8(1).

Blust, R. A. (1981). Variation in Retention Rate among Austronesian Languages. The 3rd International Conference Austronesia Linguistics.

Blust, R. A. (1999). Subgrouping, circularity and extinction: Some issues in Austronesian comparative linguistics. In $\mathrm{E}$. Zeitoun \& P. J. Li (Eds.), The 8th International Conference on Austronesian Linguistics. Academica Sinica. https://abvd.shh.mpg.de/austrones ian/language.php?id=280

Bynon, T. (1971). Historical Linguistics. Cambridge: Cambridge University Press.

Collins, J. T. (2005). Bahasa Melayu Bahasa Dunia. Jakarta: Obor.

Crowley, T. (1992). An Introduction to Historical Linguistics (1st ed.). Oxford: Oxford University Press.

Hasrah, M. T. et al. (2013). Inovasi dan Retensi dalam Dialek Hulu Tembeling. Gema Online, 13(3), 211-222.

Masrukhi, M. (2002). Refelksi Fonologis 
Protobahasa Austronesia pada Bahasa Lubu. Humaniora, 14(1), 86-93.

Moleong, L. J. (2015). Metodologi Penelitian Kualitatif. Bandung: Remaja Rosdakarya.

Poerwadi, P. (1994). Analisis Leksikostatistik terhadap BahasaBahasa di Kalimantan Tengah. Palangka Raya: Universitas Palangka Raya.

Pusat Bahasa. (2005). Penelitian Kekerabatan dan Pemetaan Bahasa di Indonesia: Kuesioner Kosakata Dasar dan Kata Budaya Dasar. Jakarta: Pusat Bahasa.

Rinah, N. J. (2010). Hubungan Kekerabatan Bahasa Malagasy dan Bahasa Maanyan [Universitas Negeri Sebelas Maret Surakarta]. https://core.ac.uk/download/pdf/1 2349308.pdf

Sudaryanto. (2015). Metode dan Aneka Teknik Analisis Bahasa.

Yogyakarta: Sanata Darma University Press.

Tiani, R. (2018). Korespondensi Fonemis Bahasa Palembang dan Bahasa Riau. Nusa, 13(3), 397404.

https://doi.org/10.14710/nusa.13.3 $.397-404$

Toha, M. (2016). Retensi dan Inovasi Fonologis Protobahasa Melayik pada Bahasa Melayu Tamiang. Ranah, 5(1), 87-100. https://doi.org/https://doi.org/10.2 6499/rnh.v5i1.40

Yulianti, A. I. (2016). Variasi Dialektal Bahasa Tomuan. Mabasan, 10(2), 36-62. 